\title{
Oxygen Consumption During Mineralization of Organic Compounds in Water Samples from a Small Sub-Tropical Reservoir (Brazil)
}

\author{
Marcela Bianchessi da Cunha-Santino ${ }^{1 *}$ and Irineu Bianchini Júnior ${ }^{2}$ \\ ${ }^{1}$ Pós Graduação em Ecologia e Recursos Naturais; Universidade Federal de São Carlos; mbcunha@cosmo.com.br; \\ Rodovia Washington Luis, km 235; C. P. 676; 13565-905; São Carlos - SP - Brazil. ${ }^{2}$ Pós Graduação em Ecologia e \\ Recursos Naturais; irineu@ power.ufscar.br; Universidade Federal de São Carlos; Departamento de Hidrobiologia; \\ Rodovia Washington Luis, km 235; C. P. 676; 13565-905; São Carlos - SP - Brazil
}

\begin{abstract}
Assays were carried out to evaluate the oxygen consumption resulting from mineralization of different organic compounds: glucose, sucrose, starch, tannic acid, lysine and glycine. The compounds were added to 1 l of water sample from Monjolinho Reservoir. Dissolved oxygen and dissolved organic carbon were monitored during 20 days and the results were fitted to first order kinetics model. During the 20 days of experiments, the oxygen consumption varied from $4.5 \mathrm{mg} . \mathrm{l}^{-1}$ (tannic acid) to $71.5 \mathrm{mg} . \mathrm{l}^{-1}$ (glucose). The highest deoxygenation rate $\left(k_{D}\right)$ was observed for mineralization of tannic acid $\left(0.321\right.$ day $\left.^{-1}\right)$ followed by glycine, starch, lysine, sucrose and glucose $(0.1004,0.0504$, $0.0486,0.0251$ and $0.0158 \mathrm{day}^{-1}$, respectively). From theoretical calculations and oxygen and carbon concentrations we obtained the stoichiometry of the mineralization processes. Stoichiometric values varied from 0.17 (tannic acid) to 2.55 (sucrose).
\end{abstract}

Key words: Oxygen consumption; aerobic mineralization; Reservoir of Monjolinho (UFSCar - São Carlos, SP)

\section{INTRODUCTION}

Dissolved Organic Matter (DOM) is the main fraction of organic material in aquatic environments and a minor part consists of Particulate Organic Matter (POM). The ratio between DOM and POM is mostly 10:1 (Wetzel, 1983). In many aquatic ecosystems large amounts of DOM and POM are channeled through microorganisms to higher trophic levels (Pomeroy and Wiebe, 1988).

DOM in lakes consists of thousands of different organic compounds, many of which may serve as microbial substrates. This mixture comprises both low and high molecular weight compounds, from which 0.5 to $5 \%$ can be easily assimilated and metabolized by microorganisms (Chróst, 1990). These compounds enclose monomers such as dissolved free amino acids and carbohydrates (Münster et al., 1992; Hanisch et al., 1996; Foreman et al., 1998; Bunte and Simon, 1999). Studies on the polymeric structure of DOM showed these substrates to be important for the heterotrophic activity in aquatics systems. The polymers include compounds such as the polypeptides, lipids, polyphenolic compounds and humic substances (Kaplan and Bott, 1983; Moran and Hodson, 1989;

* Author for correspondence 
Hessen, 1992). These monomers and polymers have to undergo extracellular enzymatic decomposition before being ready for immobilization and final oxidation by heterotrophic microorganisms (Hoppe et al., 1988). Mineralization of an organic molecule in water is also a consequence of microbial activity. As microorganisms convert the organic substrate to inorganic products (e.g. $\mathrm{CO}_{2}$ and water in aerobic mineralization) the microbial community in this process uses carbon in the substrate to increase its number and biomass. As a consequence mineralization is typically a growth-linked process (Alexander, 1991).

Aerobic mineralization displays the following features: (i) it requires the presence of oxygen; (ii) the cells keep intracellular redox balance; (iii) respiration is normally associated with the operation of tricarboxylic acid cycle and the consequent catabolism of the substrate to $\mathrm{CO}_{2}$, with absence of any partial breakdown products and (iv) this process is coupled to ATP synthesis by oxidative phosphorylation and is energetically efficient (Hamilton, 1984).

Aerobic mineralization is considered important for the cycling of DOM in aquatic systems, which prompted us to perform assays to evaluate the oxygen consumption during mineralization of organic compounds in water samples, from a eutrophic reservoir. The experiments were also used for estimating oxygen consumption rates and the stoichiometric ratios of oxygen and carbon during mineralization.

\section{MATERIALS AND METHODS}

The Reservoir of Monjolinho (22 $02^{\circ} \mathrm{S} ; 4^{\circ} 54^{\prime}$ $\mathrm{W})$ is a small artificial water system located inside of the campus of Universidade Federal de São Carlos. Its morphology is described by Nogueira and Matsumura-Tundisi (1994). The maximum depth is $3 \mathrm{~m}$. The flooded area comprises 47.157 $\mathrm{m}^{2}$; the reservoir has a volume of $73.251 \mathrm{~m}^{3}$ and a time of retention of 22.9 to 2.1 days depending on the season. Monjolinho's stream supplies water to the reservoir. The anthrophic pressure on the Monjolinho's watershed affects the water quality of the reservoir (Marinelli et al., 2000).

About $50 \mathrm{mg}$ of glucose, sucrose, starch, tannic acid, L-lysine mono chloridate and glycine were incubated in duplicate at $21.0^{\circ} \mathrm{C} \pm 0.6$, in $\mathrm{BOD}$ bottles $(250 \mathrm{ml})$ containing filtered reservoir water (with glass wool), under aerobic conditions. The reservoir water was the source of indigenous microorganisms. In order to maintain the solutions under aerobic conditions, they were oxygenated during 1 hour, to keep dissolved $\mathrm{O}_{2}$ near saturation. After oxygenation, the dissolved oxygen (DO) was measured with an oxymeter (YSI - model 58). During the daily measurements whenever the DO concentrations were below 2.0 mg. $\mathrm{l}^{-1}$, the solutions were oxygenated again until DOreached the saturation value. The oxygen consumption was estimated during 20 days. To remove the background DO consumption, two blank flasks (with water sample of reservoir) were also incubated. The initial and final concentrations of DOC (Table 1) were determined by high temperature combustion with a SHIMADZU TOC-5000A analyzer.

The consumption of oxygen was assumed to be directly related to the oxidation of the organic resource, and that this process could be represented by first-order kinetics models (Characklis, 1990; Henze et al., 1997; CunhaSantino and Bianchini Jr., 2002). Hence, the variation in DO decay and its DO consumption can be described by Equations (1) and (2), respectively:

$$
\frac{d[D O]}{d t}=-k_{D} D O
$$

where: [DO]: the change in oxygen concentration per unit time $\left[\mathrm{mg} . \mathrm{l}^{-1}\right] ; \mathrm{k}_{\mathrm{D}}$ : deoxygenation rate constant $\left[\mathrm{day}^{-}\right.$ ${ }^{1}$ ] and t: time [day].

$$
\frac{d O C}{d t}=k_{D} D O-k_{R} O C \ldots \ldots \ldots \ldots \ldots \ldots(\text { Equation } 2)
$$

where: OC: evolution of DO consumption $\left[\mathrm{mg} \cdot \mathrm{l}^{-1}\right]$ and $\mathrm{k}_{\mathrm{R}}$ : reaeration rate constant $\left[\mathrm{day}^{-1}\right]$, derived from the method of DO determination by stirring the sample when using a probe to take DO measurements.

Based on the initial and final dissolved organic carbon $\left(\mathrm{DOC}_{\mathrm{i}}\right.$ and $\left.\mathrm{DOC}_{\mathrm{f}}\right)$ the amount of mineralized carbon was estimated. From theoretical calculations, using a balanced equation of the total combustion of the organic compounds and from oxygen and carbon concentration we obtained the stoichiometry of the processes. 

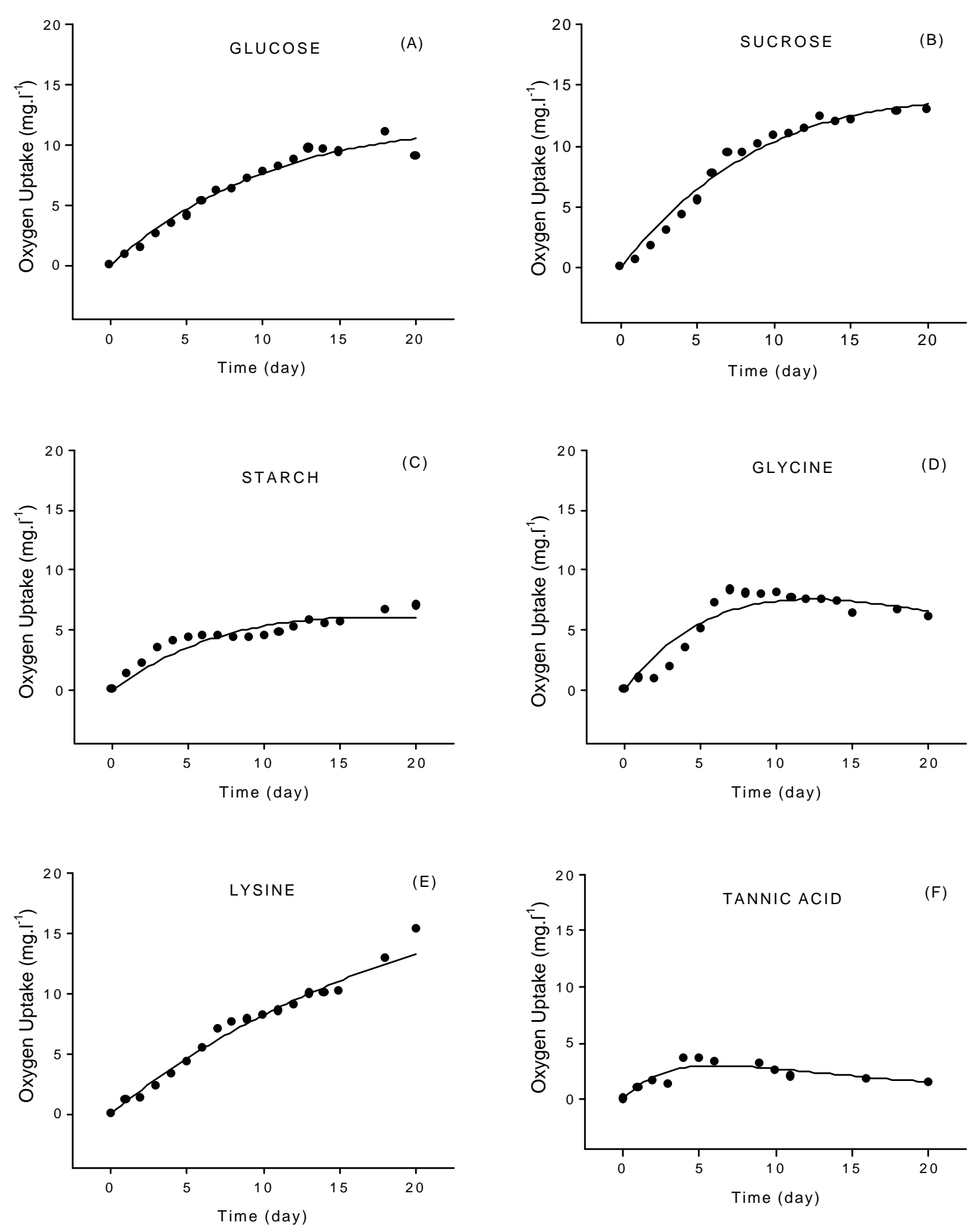

Figure 1 - Oxygen consumption during aerobic mineralization: (A) glucose, (B) sucrose, (C) starch, (D) glycine, (E) lysine and (F) tannic acid. The fittings using the kinetic model are shown as a solid line. 
Table 1 - Stoichiometry of the aerobic mineralization. (DOC $\mathrm{D}_{\mathrm{i}}$ : initial dissolved organic carbon; $\delta \mathrm{C}$ : difference between the initial and final dissolved organic carbon; $\mathrm{OC}_{\max }$ : maximum oxygen consumption; $\mathrm{OC}_{20}$ : 20-d DO obtained from the simulation of the parametric kinetics reaction of oxygen consumption; $\mathrm{k}_{\mathrm{D}}$ : DO consumption coefficient; $t_{1 / 2 D}$ : DO consumption half-time; $S 1$ : theoretical stoichiometric value; $S 2$ : stoichiometric value considering $\mathrm{OC}_{\max }$ and $\mathrm{DOC}_{\mathrm{i}} ; \mathrm{S} 3$ : stoichiometric value regarding to $\mathrm{OC}_{20}$ and $8 \mathrm{C}$ and S4: average between $\mathrm{S} 2$ and $\mathrm{S} 3$ ).

\begin{tabular}{|c|c|c|c|c|c|c|c|c|c|c|}
\hline Substratum & $\begin{array}{l}\mathrm{DOC}_{\mathrm{i}} \\
\mathrm{mg}^{-1} \mathrm{I}^{-1} \\
\end{array}$ & $\begin{array}{c}\delta \mathrm{C} \\
\mathrm{mg} . .^{-1} \\
\end{array}$ & $\begin{array}{l}\mathrm{OC}_{\max } \\
\mathrm{mg} \cdot \mathrm{l}^{-1}\end{array}$ & $\begin{array}{l}\mathrm{OC}_{20} \\
\mathrm{mg} \cdot .^{-1} \\
\end{array}$ & $\begin{array}{c}\mathrm{k}_{\mathrm{D}} \\
\left(\mathrm{day}^{-1}\right)\end{array}$ & $\begin{array}{c}\mathrm{t}_{1 / 2} \\
\text { (day) }\end{array}$ & S1 & S2 & S3 & S4 \\
\hline glucose & 25.60 & 7.92 & 71.50 & 19.41 & 0.016 & 43.32 & 2.66 & 2.79 & 2.45 & 2.62 \\
\hline sucrose & 25.88 & 12.95 & 64.11 & 25.30 & 0.025 & 27.72 & 2.66 & 2.47 & 1.95 & 2.21 \\
\hline starch & 19.65 & 12.01 & 18.94 & 12.10 & 0.050 & 13.86 & 2.44 & 0.96 & 0.82 & 0.89 \\
\hline glycine & 19.36 & 11.56 & 16.79 & 14.53 & 0.100 & 6.93 & 0.66 & 0.86 & 1.25 & 1.06 \\
\hline lysine & 22.73 & 15.87 & 21.30 & 13.25 & 0.048 & 14.44 & 3.22 & 0.93 & 0.83 & 0.88 \\
\hline tannic acid & 45.73 & 23.22 & 4.48 & 4.47 & 0.321 & 2.15 & 2.32 & 0.17 & 0.19 & 0.18 \\
\hline
\end{tabular}

\section{RESULTS}

The kinetics of oxygen consumption from the aerobic mineralization of glucose, sucrose, starch, tannic acid, lysine and glycine are shown in Figure 1 (the values referred to the average of the flasks). Equation 2 shows the oxygenation effect from stirring for the measurements of DO consumption. In order to avoid this artifact, the averaged reaeration rate was taken for all organic solutes $\left(k_{R}=0.06512\right.$ day $\left.^{-1}\right)$. This coefficient was estimated from the bottles with tannic acid solution, since oxygenation prevailed in this substrate.

The fittings with the kinetics model showed that in the mineralization of the substrates oxygen consumption $\left(\mathrm{OC}_{\max }\right)$ ranged from $4.48 \mathrm{mg} . \mathrm{l}^{-1}$ (tannic acid) to $71.50 \mathrm{mg} .1^{-1}$ (glucose) (Table 1). Deoxygenation rates $\left(\mathrm{k}_{\mathrm{D}}\right)$ and the half-time $\left(\mathrm{t}_{1 / 2 \mathrm{D}}\right)$ of the aerobic mineralization were also obtained. The $\mathrm{k}_{\mathrm{D}}$ ranged from 0.016 to 0.321 day $^{-1}$ and $t_{1 / 2 \mathrm{D}}$ lied between 2.15 to 43.32 days (Table 1). The highest $\mathrm{k}_{\mathrm{D}}$ was observed during the mineralization of tannic acid $\left(0.321\right.$ day $\left.^{-1}\right)$, followed in decreasing order by glycine, starch, lysine, sucrose and glucose $(0.1004 ; 0.0504$; 0.0486 ; 0.0251 ; and 0.0158 day $^{-1}$, respectively).

The stoichiometry was related to the amount of oxygen used during carbon oxidation. From theoretical calculations for the complete combustion of the substrates the stoichiometry $(\mathrm{O} / \mathrm{C}$ relation) was obtained for each compound (S1 in Table 1). The evaluation of the experimental stoichiometric ratio, was obtained from: (i) the maximum value of the accumulated oxygen consumption $\left(\mathrm{OC}_{\max }\right)$ estimated by the kinetics fittings, divided by $\mathrm{DOC}_{\mathrm{i}}$ (initial amount of organic carbon), resulting the S2 value (Table 1); (ii) the simulated value of the oxygen consumption corresponding to the 20th-day $\left(\mathrm{OC}_{20}\right)$, estimated by the kinetics model; divided by the difference $(\delta \mathrm{C})$ between the contents of carbon in the beginning $\left(\mathrm{DOC}_{\mathrm{i}}\right)$ and the final $\left(\mathrm{DOC}_{\mathrm{f}}\right)$, giving the $\mathrm{S} 3$ value (Table 1). The average between S2 and S3 (S4 in Table 1), ranged from 0.18 to 2.62 , while the theoretical values varied from 0.6 to 2.6 .

\section{DISCUSSION}

Several studies have assessed the temporal evolution of oxygen consumption to describe the metabolic activity of microorganisms involved in the mineralization process of organic resources (Bitar and Bianchini Jr., 1994; Farjalla et al., 1999; Brum et al., 1999). From the kinetics point of view, the oxygen consumption during the decay of such organic compounds is similar to that observed in the mineralization process of several organic substrata such as plant detritus (McAvoy et al., 1998). Mineralization involved considerable consumption of dissolved oxygen in the beginning of the process, followed by a tendency to stabilization. In the final stages of mineralization reoxygenation due to the method adopted (stirring) occurred.

The effect of microbial degradation in the regulation of DOC concentrations in the aquatic ecosystems was directly related with $\mathrm{k}_{\mathrm{D}}$. Mineralization processes with high $\mathrm{k}_{\mathrm{D}}$ (Table 1) (short half-life times) corresponded to a higher biodegradability potential. Due to the high $\mathrm{k}_{\mathrm{D}}$, these compounds did not tend to accumulate in the ecosystem. In contrast, 
fractions with low $\mathrm{k}_{\mathrm{D}}$ (long half-life times) probably remained unaffected in the aquatic ecosystems for long periods, and consequently were present at the highest concentrations. The fractions of COD with their different $\mathrm{k}_{\mathrm{D}}$ acted directly on the quality and quantity of the carbon recycling in the reservoir. Another fact related to the biodegradability was the natural microbiota from the reservoir water. The adaptability of these organisms to the aerobic immobilization and mineralization also affected the concentrations of organic compounds in the environment.

The processing of a given substrate presents two important parameters: the stoichiometry and the reaction coefficient. In this case, the stoichiometry determines the extension of the mineralization process, representing quantitative information on the consumption of reagents and formed products. The coefficients include the specific rates of substratum removal, of oxygen consumption and of biomass production. These coefficients determine how fast changes occur (Characklis, 1990). Stoichiometry also represents an indirect way to predict the pathways for microbial metabolic activity.

The data indicated that the samples of glucose, sucrose, starch, tannic acid, lysine and glycine at the end (20 days) had lost carbon. The difference in the amount of carbon was transformed into $\mathrm{CO}_{2}$ through the microbial metabolism, or it was submitted to chemical oxidation. The values found for the stoichiometric global ratios depended on the type of organic compound. On average, glucose and sucrose showed a stoichiometric coefficient similar to the theoretical one. In the mineralization of glycine, the stoichiometric value was higher. On the other hand, stoichiometry coefficients for the mineralization of starch, tannic acid and lysine were smaller than the theoretical values.

Information on stoichiometry comes from principles such as conservation of mass and of chemical elements (Characklis, 1990). Thus, the agreement between theoretical and experimental values provides information about the microbial metabolic pathways. Therefore, the agreement between theoretical and experimental values probably indicates that the principal route for the carbohydrate catabolism was the EmbdenMeyerhof pathway and the Krebs cycle.
Regarding the stoichiometric values, the internal recycling by the prevalence of the assimilation process by the microorganisms and the direct reusable inorganic nutrient $\left(\mathrm{CO}_{2}\right)$ probably influenced the total amount of carbon consumption during the aerobic mineralization of glycine and consequently the coefficient rates values from this oxidation.

Another factor that contributed to the higher stoichiometric value was the oxidation of ammonium to produce nitrate. This process was necessarily aerobic and mediated by microorganisms. Because nitrification also utilized oxygen, measured DO were probably overrated. Yet another point to consider in this case is the anapleirotic reaction, which is a replenishing reaction in intermediary metabolism. An example is the carboxilation of pyruvate to oxaloacetate to replenish oxaloacetate in the tricarboxylic acid cycle after its withdrawal for the synthesis of amino acids (Lawrence, 1995). The carboxylation reaction may have affected the contents of organic carbon of the compounds.

For starch, the colloidal characteristics of the molecules probably interfered in the carbon analysis. Starch, like cellulose, is composed only of D-glucose units joined by $\beta$-glycosidic linkages. It is normally a mixture of two types of polysaccharides: amylose and amylopectin. In most starches there is about $25 \%$ amylose to $75 \%$ of amylopectin. Amylopectin is hydrophobic, with low solubility in water, and may form a very viscous colloidal system (Avigad and Dey, 1997). Due to its high viscosity, starch may adsorb onto the glass wall and therefore the amount of DOC in the samples may be underestimated.

Tannins comprise a heterogeneous group of high molecular weight (500-5000) plant polyphenols. They contain sufficient phenolic hydroxyl groups to permit the formation of stable cross-links with proteins, and as a result of this cross-linking enzymes may be inhibited. Tannins are classified into two broad groups: the hydrolysable ones and the condensed or non-hydrolysable tannins. The first group usually contains a central core of glucose or other polyhydric alcohol sterified with gallic acid or hexahydroxydiphenic acid. Condensed tannins are mostly flavolans or polymers of cathechins or leucoanthocyanidins. They are mostly resistant to breakdown (Walker, 1975). Probably the tannic acid used possessed a non-hydrolyzed fraction that may have a negative effect on enzyme activities, driving down the growth efficiency of microorganisms. Foreman et al. (1998) also showed similar result on the degradation of tannin. According to our 
study the high $\mathrm{k}_{\mathrm{D}}$ value obtained for tannic acid $\left(0.321\right.$ day $\left.^{-1}\right)$, probably was related to the mineralization of hydrolyzed fraction. Tannin also denatured proteins or injured plasma membrane of microorganisms (Tortora et al., 1997). The stoichiometric coefficients indicated that in the aerobic decay of tannic acid chemical oxidation probably prevailed over biochemical oxidation (mediated by microorganisms). In this case chemical oxidation may have had the interference of other oxidizing agents such as hydrogen peroxide, nitrate, sulfate etc. The use of other oxidizing agents could consume the organic carbon fraction of the tannic acid molecule, thus decreasing the stoichiometric ratio.

The initial reaction in the catabolism of amino acids usually involves removal of either the amino group or the carboxyl group. Deamination can take any one of several different forms, depending on the nature of the population involved in the catabolic process and sometimes on the conditions under which it has been grown. In the oxidative deamination reaction, the amino acid is converted to the corresponding keto acid plus $\mathrm{NH}_{3}$ and water. Occasionally, the reaction leads to the formation of hydrogen peroxide instead of water, which is one of the reasons why some microorganisms synthesize the enzyme catalase that catalyses the breakdown of hydrogen peroxide (Rose, 1976). The possible formation of $\mathrm{H}_{2} \mathrm{O}_{2}$ in lysine mineralization led to an underestimation of the OC consumption in the samples, therefore decreasing the stoichiometric coefficients.

Aquatic ecosystems of different water quality are frequently characterized by different concentrations of DOC and nutrient supplies. The rates of oxygen consumption measured through the metabolism of heterotrophic microorganisms suggest the capacity of the reservoir in storing or converting organic compounds. From the assays reported here, it was shown that in Monjolinho Reservoir glucose is the organic substrate with the highest oxygen consumption in the mineralization. On the other hand, this mineralization process occurred at the lowest rates. Considering the retention time of Monjolinho Reservoir and the $\mathrm{k}_{\mathrm{D}}$ obtained in this study, in the wet season (2.21 days) the tannic acid (9.14 mg. $\mathrm{l}^{-1}$ ) and glucose (9.10 mg. $\mathrm{l}^{-1}$ ) oxidized the same quantities of organic carbon. In the dry season (retention time $=29.9$ days) glucose displayed an oxygen consumption 5.4 times higher than tannic acid (18.6 mg. $\left.1^{-1}\right)$.

\section{ACKNOWLEDGEMENTS}

The authors thank Coordenadoria de Aperfeiçoamento de Pessoal de Nível Superior (CAPES) for the partial financial support of this work. We are also indebted to Dr. Osvaldo $\mathrm{N}$. Oliveira Jr. (IFSC-USP) for the critical reading of the manuscript.

\section{RESUMO}

Ensaios foram realizados para avaliar o consumo de oxigênio resultante da mineralização aeróbia de diferentes compostos orgânicos: glicose, sacarose, amido, ácido tânico, lisina e glicina. Os compostos foram adicionados a 11 de amostra de água do

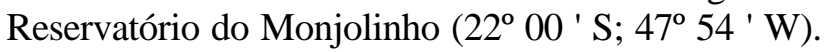
As concentrações de oxigênio e de carbono orgânico dissolvidos foram determinadas durante 20 dias. Os resultados foram ajustados a modelos cinéticos de primeira ordem, observou-se que durante os 20 dias de experimento o consumo de oxigênio variou de 4,5 mg. $1^{-1}$ (ácido tânico) a 71,5 mg. $1^{-1}$ (glicose). Os coeficientes de desoxigenação $\left(\mathrm{k}_{\mathrm{D}}\right)$ mais elevados foram observados para o ácido tânico $\left(0,321 \mathrm{dia}^{-1}\right)$ seguido pela glicina, amido, lisina, sacarose e glicose $\left(0,1004,0,0504,0,0486,0,0251\right.$ e $0,0158 \mathrm{dia}^{-1}$, respectivamente). A partir de cálculos teóricos e das concentrações de oxigênio e de carbono foram obtidas as estequiometrias dos processos de mineralização. Os valores estequiométricos variaram de 0,17 (ácido tânico) a 2,55 (sacarose).

\section{REFERENCES}

Alexander, M. (1991), Biodegradation of chemicals of environmental concern. Science, 211 : (9), 132-138.

Avigad, G. and Dey, P. M. (1997), Carbohydrate metabolism: storage carbohydrates. In: Dey, P. M. and Harborne, J. B. (ed.). Plant Biochemistry. San Diego : Academic Press. pp. 143-204.

Bitar, A. L. and Bianchini Jr., I. (1994), Efeito do teor de matéria orgânica dissolvida sobre as taxas de seu processo de mineralização. Paper presented at I Seminário sobre Qualidade Águas Continentais no MERCOSUL. Porto Alegre : ABRH. pp. 311-329. 
Brum, P. R.; Farjalla, V. F.; Gonçalves Jr., J. F.; Santos, A. M.; Pôrto, M. T.; Vieira, E. D. R.; Ferreira, F. M. and Bianchini Jr., I. (1999), Aspects of the uptake of dissolved oxygen in Cabiúnas and Imboassica Lagoons (Macaé, RJ). Brazil. Arch. Biol. Technol., 42 : (4), 433-440.

Bunte, C. and Simon, M. (1999), Bacterioplankton turnover of dissolved free monosaccharides in a mesotrophic lake. Limnol. Oceanogr., 44 : (8), 1862-1870.

Characklis, W. G. (1990), Kinetics of microbial transformations. In: Characklis, W. G. and Marshall, K. C. (eds.). Biofilms. New York : John Wiley and Sons. pp. 233-264.

Chróst, R. J. (1990), Microbial ectoenzymes in aquatic environments. In: Overbeck, J. and Chróst, R. J. (eds.). Aquatic Microbial Ecology Biochemical and molecular approach. New York : Spring-Verlag. pp. 47-78.

Cunha-Santino, M. B. and Bianchini Jr., I. (2002), Humic substance mineralization in a tropical oxbow lake (São Paulo, Brazil). Hydrobiol., 468, 33-43.

Farjalla, V. F.; Marinho, C. C. and Esteves, F. A. (1999), Uptake of oxygen in the initial stages of decomposition of aquatic macrophytes and detritus from terrestrial vegetation in a tropical coastal lagoon. Acta Limnol. Brasil., 11 : (2), 185-193.

Foreman, C. M.; Franchini, P. and Sinsabaugh, R. L. (1998), The trophic dynamics of riverine bacterioplankton: relationships among substrate availability, ectoenzyme kinetics, and growth. Limnol. Oceanogr., 43 : (6), 1344-1352.

Hamilton, W. A. (1984), Energy sources for microbial growth: an overview. In: Codd, G. A. (ed.). Aspects of microbial metabolism and ecology. Orlando: Academic Press. pp. 35-57.

Hanisch, K.; Schweitzer, B. and Simon, M. (1996), Use of dissolved carbohydrate by planktonic bacteria in a mesotrophic lake. Microb. Ecol., 31, 41-55.

Henze, M.; Harremoës, P.; Jansen, J. C. and Arvin, E. (1997), Wastewater Treatment- Biological and chemical processes. Berlin : Springer-Verlag.

Hessen, D. O. (192), Dissolved organic carbon in a humic lake: effects on bacterial production and respiration. Hydrobiol., 229, 115-123.

Hoppe, H. G.; Kim, S. J. and Gocke, K. (1988) Microbial decomposition in aquatic environments; combined process of extracellular enzyme activity and substrate uptake. Appl. Environ. Microb., 54 : (30), 784-790.
Kaplan, L. A. and Bott, T. L. (1983), Microbial heterotrophic utilization of dissolved organic matter in a piedmont stream. Freshwater Biol., 13, 363-377.

Lawrence, E. (1995), Henderson's dictionary of biological terms. New York : Jonh Wiley and Sons.

Marinelli, C. E.; Moretto, E. M.; Brucha, G. and Lucca, J. V. (2000), Limnologia. In: Espíndola, E. L. G.; Silva, J. S. V.; Marinelli, C. E. and Abdon, M. M. A Bacia Hidrográfica do Rio do Monjolinho. São Carlos : RIMA.

McAvoy, D. C.; Grady Jr., C. P. L.; Blok, J.; Feijel, T. C. J.; Federle, T. W. and Larson, R. J. (1998), A simplified modeling approach using microbial growth kinetics for predicting exposure concentrations of organic chemicals in treated waterwaste effluents. Chemosp., 36 : (10), 2291-2304.

Moran, M. A. and Hodson, R. E. (1989), Formation and bacterial utilization of dissolved organic carbon derived from detrital lignicellulose. Limnol. Oceanogr., 34 : (6), 1034-1047.

Münster, U.; Nurminen, J.; Einiö, P. and Overbeck, J. (1992), Extracellular enzymes in a small polyhumic lake: origin, distribution and activities. Hydrobiol., 243-244, 47-59.

Nogueira, M. G. and Matsumura-Tundisi, T. (1994), Limnologia de um sistema raso (represa do Monjolinho - São Carlos, SP). I - Dinâmica das variáveis físicas e químicas. Rev. Brasil. Biol., 54, 147-159.

Pomeroy, L. R. and Wiebe, W. J. (1988), Energetics of microbial food webs. Hydrobiol., 159, 7-18.

Rose, A. H. (1976), Chemical Microbiology - an introduction to microbial physiology. Butterworths, London.

Tortora, G. J.; Funke, B. R. and Case, C. L. (1997), Microbiology - an Introduction. Addison Wesley Longman, Inc., California.

Walker, J. R. L. (1975), The biology of plant phenolics. Edward Arnold (Publishers) Limited, London.

Wetzel, R. G. (1983), Limnology. Philadelphia : Saunders.

Received: December 11, 2001; Revised: June, 2002; Accepted: November 19, 2002. 